\title{
SISTEM PERADILAN EDUKATIF DALAM SISTEM PERADILAN ANAK DI INDONESIA
}

\author{
Asliani Harahap \\ Fakultas Hukum, Universitas Muhammadiyah Sumatera Utara \\ Jl. Kapt. Mukhtar Basri Nomor 3, Medan - Sumatera Utara \\ Email: aslianiharahap@umsu.ac.id
}

\begin{abstract}
Abstrak
Sistem peradilan edukatif harus menjadi prioritas hakim dalam mengambil keputusan. Menempatkan anak-anak di penjara akan selalu menjadi pilihan terakhir dengan periode waktu sesingkat mungkin. Menempatkan anak-anak di lembaga yang memiliki manfaat dan fungsi sosial serta perbaikan untuk anak-anak lebih baik, tetapi diharapkan bahwa lembagalembaga ini dapat memberikan perawatan, perlindungan, pendidikan dan keterampilan khusus yang bersifat pendidikan sehingga mereka dapat digunakan untuk membantu mereka konstruksi sosial dan produktif di masyarakat. Sistem hukuman pendidikan dalam sistem pengadilan anak dalam penerapannya bermanfaat bagi anak-anak sebagai pelaku kejahatan, yang diharapkan dalam perlindungan anak-anak karena para pelaku kejahatan harus mendapat perhatian serius dari pemerintah. Anak-anak yang mematuhi hukum dalam posisi anak-anak sebagai pelaku kejahatan, selain membutuhkan perlindungan dan keamanan diri juga memerlukan peraturan hukum yang menjamin kepentingan anak-anak. Manfaat bagi anakanak sebagai pelaku kejahatan adalah agar perkembangan jiwa anak tidak terganggu dan untuk perlindungan dan kepentingan anak.
\end{abstract}

\section{Kata Kunci: Sistem, Peradilan, Edukatif, Anak}

\section{Abstract}

Educative judicial system must be the priority of the judge in making a decision. Placing children in prison will always be the last choice with the shortest possible period of time. Placing children in institutions that have social benefits and functions as well as improvements for children is better, but it is hoped that these institutions can provide care, protection, education and special skills that are educational in nature so that they can be used to help them social construction and productive in the community. The educational punishment system in the juvenile court system in its application is beneficial to children as perpetrators of crimes, which is expected in the protection of children as perpetrators of criminal offenses should receive serious attention from the government. Children who are compliant with the law in the position of children as perpetrators of crime, in addition to needing protection and self-security also require legal regulations that guarantee the interests of children. The benefit for children as perpetrators of crime is that the development of the child's soul is not disturbed and for the protection and interests of the child.

Keywords: System, Judicial, Educative, Children

\section{PENDAHULUAN}

Berbagai tindak kejahatan sering terjadi di masyarakat, misalnya pencurian, perampokan, penipuan, pembunuhan dan sebagainya. Dari semua tindak kejahatan tersebut 
DE LEGA LATA

Jurnal Ilmu Hukum

FAKULTAS HUKUM UMSU
Sistem Peradilan Edukatif...(Asliani Harahap)

Volume 3 Nomor 2, Juli-Desember 2018, 217-229

DOI: https://doi.org/10.30596/dll.v3i2.3152

terjadi dikarenakan sebagai macam faktor yang mempengaruhinya, seperti keterpaksaan seseorang melakukan tindak kejahatan pencurian yang dikarenakan faktor ekonomi, faktor lingkungan atau terikut dengan lingkungan yang ada disekotarnya dan sebagainya. Kesemua tindak kejahatan yang terjadi tersebut harus mendapatkan ganjaran yang setimpal atau seimbang, sehingga dengan demikian agar ketertiban, ketentraman dan rasa keadilan di masyarakat dapat tercapai dengan baik.

Menurut Satjipto Raharjo menjelaskan bahwa hukum adalah karya manusia berupa norma-norma berisikan petunjuk-petunjuk tingkah laku. Hukum merupakan pencerminan dari kehendak manusia tentang bagaimana seharusnya masyarakat dibina dan kemana harus diarahkan. Oleh karena itu, pertama-tama hukum mengandung rekaman ide-ide yang dipilih oleh masyarakat tempat hukum diciptakan, ide-ide tersebut berupa ide mengenai keadilan. Sedangkan menurut J.C.T Simorangkir dan Woerjono Sastropranoto menjelaskan hukum adalah peraturan-peraturan bersifat memaksa yang dibuat oleh Badan-badan resmi yang berwajib, yang menentukan tingkah laku manusia dalam lingkungan masyarakat, pelanggaran terhadap peraturan-peraturan tadi berakibat diambilnya tindakan hukuman (Albert Rumokoy, 2016, h. 52).

Hukum Konvensional, hukum pidana termasuk dibidang hukum politik. Artinya hukum pidana mengatur hubungan antara warga dengan negara dan menitik beratkan kepada kepentingan umum atau kepentingan publik. Menurut Leo Polak hukum Pidana adalah bagian dari hukum yang paling celaka, sebab ia tidak tahu mengapa ia itu dihukum, dan dengan siasia membuktikan bahwa dirinya dihukum (Teguh Prasetyo, 2015, h. 2).

Membahas hukum pidana dengan segala aspeknya (aspek sifat melawan hukum, kesalahan dan pidana) akan selalu menarik perhatian, berhubungan dengan sifat dan fungsinya yang istimewa. Hukum Pidana adalah bagian dari keseluruhan hukum yang berlaku disuatu negara yang mengadkan dasar-dasar dan aturan-aturan, yakni menentukan perbuatan yang tidak boleh dilakukan yang dilarang dengan disertai ancaman dan disertai saknsi, menentukan kapan dan dalam hal-hal apa kepada mereka yang telah melanggar laranganlarangan itu, serta menentukan dengan cara bagaimana pengenaan pidana itu dapat dilaksanakan (Moeljanto, 2008, h. 1).

Seseorang yang telah melakukan perbuatan atau tindak pidana, maka terhadap orang tersebut diancaman suatu Pidana, bagian yang tidak terpisahkan dalam hukum Pidana adalah masalah pemidanaan. Bukan merupakan hukum pidana apabila suatu peraturan hanya norma tanpa diikuti dengan suatu ancaman pidana. Meski bukan yang terutama akan tetapi sifat dari Pidana merupakan suatu penderitaan. Pidana yang dijatuhkan bagi mereka yang dianggap bersalah merupakan sifat derita yang harus dijalaninya walaupun demikian sanksi pidana bukanlah semata-mata bertujuan untuk memberika rasa derita. Pidana yang dijatuhakn diharapkan dapat menyelesaikan konflik serta memuaskan pihak yang dendam baik masyarakat sendiri maupun pihak yang dirugikan menjadi korban kejahatan (Andi Hamzah, 2008, h. 29). 
DE LEGA LATA

Jurnal Ilmu Hukum

FAKULTAS HUKUM UMSU
Sistem Peradilan Edukatif...(Asliani Harahap)

Volume 3 Nomor 2, Juli-Desember 2018, 217-229

DOI: https://doi.org/10.30596/dll.v3i2.3152

\section{METODE PENELITIAN}

Jenis metode penelitian yang digunakan dalam penelitian ini adalah penelitian yuridis normatif. Penelitian yuridis normatif adalah penelitian yang digunakan untuk mengkaji penerapan kaedah-kaedah atau norma-norma hukum (Johnny Ibrahim, 2008, h. 282), sedangkan menurut Zainuddin Ali (2011, h. 24). penelitian yuridis normatif membahas doktrin-doktrin atau asas-asas dalam ilmu hukum. Berdasarkan kegunaannya, jenis metode penelitian yuridis normatif berguna untuk mengetahui atau mengenal apakah dan bagaimanakah hukum positifnya mengenai suatu masalah tertentu dan juga dapat menjelaskan atau menerangkan kepada orang lain apakah dan bagaimanakah hukumnya mengenai peristiwa atau masalah yang tertentu (C. F. G. Sunaryati Hartono, 1994, h. 140).

Sumber data yang digunakan dalam penelitian ini adalah data sekunder yang didukung oleh data primer. Data sekunder terdiri dari bahan hukum primer, bahan hukum sekunder dan bahan hukum tersier, yaitu; perundang-undangan, catatan-catatan resmi atau risalah dalam pembuatan perudang-undangan dan putusan-putusan hakim (Peter Mahmud Marzuki, 2006, h. 141). Di dalam penelitian ini yang menjadi data primer tersebut adalah Undang-Undang Nomor 11 Tahun 2012 Tentang Sistem Peradilan Pidana Anak, Undang-Undang Nomor 35 Tahun 2014 tentang Perlindungan Anak, Kitab Undang-undanga Hukum Pidana (KUHP). Bahan hukum sekunder adalah bahan yang memberikan penjelasan mengenai bahan hukum primer, seperti; buku, skripsi, tesis, disertasi, hasil penelitian lain yang relevan dengan penelitian, naskah akademik, pidato pengukuhan guru besar. Bahan hukum tersier adalah bahan hukum yang memberikan petunjuk atau penjelasan terhadap bahan hukum primer dan sekunder, seperti; kamus hukum, encyclopedia dan lain-lain.

Teknik pengumpulan data sekunder pada penelitian ini menggunakan studi dokumen yang memiliki arti bahwa data yang diperoleh melalui penelusuran kepustakaan (library research) berupa data skunder yang ditabulasi kemudian disistemasikan dengan memilih perangkat-perangkat hukum yang relevan dengan objek penelitian yaitu terkait dengan sistem pemidanaan edukatif terhadap anak. Keseluruhan data ini kemudian digunakan untuk mendapatkan landasan teoritis berupa bahan hukum positif, pendapat-pendapat atau tulisan para ahli atau pihak lain berupa informasi baik dalam bentuk formal maupun melalui naskah resmi.

\section{PEMBAHASAN}

\section{Anak Sebagai Pelaku Tindak Pidana}

Anak merupakan harapan bangsa dan apabila sudah sampai saat nya akan menggantikan generasi tua dalam melanjutkan roda kehidupan negara, dengan demikian anak perlu dibina dengan baik agar mereka tidak salah dalam kehidupannya kelak. Setiap komponen bangsa baik pemerintah maupun non pemerintah memiliki kewajiban untuk secara serius memberi perhatian terhadap pertumbuhan dan perkembangan anak. Secara nasional defenisi anak menurut perundang-undangan, diantaranya menjelaskan anak adalah seorang yang belum mencapai usia 21 tahun atau belum menikah. Oleh karena itu, anak tidak dapat dikenakan 
Jurnal Ilmu Hukum

FAKULTAS HUKUM UMSU
Sistem Peradilan Edukatif...(Asliani Harahap)

Volume 3 Nomor 2, Juli-Desember 2018, 217-229

DOI: https://doi.org/10.30596/dll.v3i2.3152

pertanggung jawaban pidana secara penuh, karena seorang anak masih mempunyai keterbatasan dan kemampuan berpikir dan berada dalam pengawasan orang tua atau walinya (Marlina, 2012, h. 33).

Berdasarkan Undang-undang Nomor 3 Tahun 1997 Tentang Pengadilan Anak memberikan pengertian anak nakal adalah: "Anak yang melakukan tindak pidana atau anak yang melakukan perbuatan yang dinyatakan terlarang bagi anak, baik menurut peraturan perundang-undangan maupun peraturan hukum lain yang berlaku dalam masyarakat yang bersangkutan" (Marlina, 2012, h. 33). Menurut Tim Proyeksi Juvenile Deliquency yaitu Wagiati Soetedjo memberikan perumusan mengenai Juvenile Deliquency yaitu sebagai suatu tindakan atau perbuatan yang dilakukan oleh seorang anak yang dianggap bertentangan dengan ketentuan-letentuan hukum yang berlaku disuatu negara dan yang oleh masyarakat itu sendiri dirasakan serta ditafsirkan sebagai perbuatan tercela. Dengan demikian dapat disimpulkan bahwa Juvenile Deliquency adalah suatu tindakan atau perbuatan pelanggaran norma, baik norma hukum maupun norma sosial yang dilakukan oleh anak-anak usia muda.

Konsep tentang anak nakal menurut Romli Atmasasmita dalam Wagiati Soetodjo penggunaan istilah 'juvenile delinquency' adalah setiap perbuatan atau tingkah laku seseorang anak dibawah umur 18 tahun dan belum kawin yang merupakan pelanggaran terhadap normanorma hukum yang berlaku serta dapat membahayakan perkembangan pribadi sianak yang bersangkutan (Wagiati Soetedjo, 2013: 11) pengertian anak dalam kaitan dengan perilaku anak nakal (juvenile deliquency), biasanya dilakukan dengan mendasarkan pada tingkatan usia, dalam arti tingkatan usia berapakah seseorang dikategorikan sebagai anak (Nashriana, 2014, h. 8). Batas usia seseorang yang layak dalam pengertian hukum nasional, telah dirumuskan ke dalam bangunan-bangunan pengertian yang diletakkan oleh spesifikasi hukum seperti berikut ini: (Nashriana, 2014, h. 9).

a. Undang-Undang Nomor 11 Tahun 2012 Tentang Sistem Peradilan Pidana Undang-undang Nomor 11 Tahun 2012 Tentang Sistem Peradilan Anak dalam Pasal 1 ayat 3 merumuskan bahwa anak yang berkonflik dengan hukum yang selanjutnya disebut anak adalah anak yang telah berumur 12 (dua belas) tahun, tetapi belum berumur 18 Tahun yang diduga melakukan tindak Pidana. batas usia anak memberikan pengelompokkan terhadap seseorang untuk dapat disebut sebagai anak. Yang bermaksud dengan batas usia anak adalah pengelompokan usia maksimum sebagai wujud kemampuan anak dalam status hukum. Sehingga anak tersebut beralih menjadi usia dewasa atau menjadi seorang subjek hukum yang dapat bertanggung jawab secara mandiri terhadap perbuatan-perbuatan dan tindakan - tindakan hukum yang dilakukan anak itu. Untuk menetapkan ketentuan hukum yang lebih berprospek dalam meletakkan batas usia maksimum seorang anak. Akan ditemukan pendapat yang sangat beraneka ragam kedudukan hukum yang diberikan pada status kedewasaan seseorang anak.

b. Undang-undang Nomor 35 Tahun 2014 tentang Perlindungan Anak

Pasal 1 ayat 1 disebutkan bahwa yang bermaksud dengan anak adalah seseorang yang belum berusia 18 tahun, termasuk anak yang masih dalam kandungan. Perlindungan anak dapat juga diartikan sebagai segala upaya yang dutujukan untuk 
Jurnal Ilmu Hukum

FAKULTAS HUKUM UMSU
Sistem Peradilan Edukatif...(Asliani Harahap)

Volume 3 Nomor 2, Juli-Desember 2018, 217-229 DOI: https://doi.org/10.30596/dll.v3i2.3152

mencegah, rehabilitasi dan memberdayakan anak yang mengalami tindak perlakuan salah, eksploitasi, dan penelantaran agar dapat menjadmin kelangsungan hidup dan tumbuh kembang secara wajar, baik fisik mental maupun sosialnya. Batasan usia juga dapat diliah pada dokumen-dokumen internasional seperti:

1) Task force on juvenile deliquency prevention, menentukan bahwa seyogiyanya batas usia penentuan seseorang dikategorikan sebagai anak dalam Konteks pertanggungjawaban pidananya, ditetapkan usia terendah 10 tahun dan batas antara 16-18 tahun.

2) Resolusi Persatuan Bangsa-Bangsa 40/33 tentang UN Standard Minimum Rules For The Administration of Juvenile Justice (Beijing Rules) menetapkan batasan yaitu seseorang yang berusia 7-18 tahun.

3) Resolusi Persatuan Bangsa-Bangsa 45/113 hanya menentukan batas 18 tahun, artinya anak adalah seseorang yang berusia dibawah 18 tahun.

Anak memiliki peras strategis yang secara tegas dinyatakan bahwa negara menjamin hak setiap anak atas kelangsungan hidup, tumbuh dan berkembang serta atas perlindungan dari keketasan dan diskriminasi (Nashriana, 2014, h. 62). Oleh karena itu, masalah perlindungan hukum bagi anak merupakan salah satu cara melindungi tunas bangsa dimasa depan, perlindungan hukum terhadao anak menyangkut tentang semua aturan hukum yang berlaku. Perlindungan ini perlu karena anak merupakan bagian masyarakat yang mempunyai keterbatasan secara fisik dan mental, oleh karena itu anak memerlukan perlindungan dan perawatan khusus (Marlina, 2012, h.42).

Efektifitas penyelenggaraan perlindungan anak dengan undang-undang ini dibentuk Komisi Perlindungan Anak Indonesia (KPAI) yang bersifat Independen Komisi Perlindungan Anak Indonesia (KPAI) adalah lembaga independen yang kedudukannya setingkat dengan Komisi Negara yang dibentuk berdasarkan Amanat Keppres 77/2003 dalam rangka untuk meningkatkan efektifitas penyelenggaraan perlindungan anak di Indonesia.

\section{Sistem Pemidanaan Edukatif Terhadap Anak}

Seorang anak karena sesuatu hal harus dihadapkan ke depan pengadilan dan kemudian dipersalahkan maka potensi anak untuk tumbuh sebagai masa depan harus diperhitungkan sedemikian rupa, sehingga jangan karena penanganan yang salah dan bersifat formalitas, potensi anak yang sedemikian rupa justru berkembang ke arah yang negatif dan berbahaya. Tujuan pemidanaan adalah untuk menyelamatkan anak tersebut agar tidak menjadi penjahat terlebih lebih jadi residivis yang justru jauh lebih berbahaya dari penjahat dan residivis.

Mempertimbangkan keadaan kejiwaan anak, yang juga melipuuti penyimpangan dari norma-norma yang lebih luas, termasuk diantaranya kepatutan yang telah dikenal dengan masyarakat sudah jelas pengertian kenakalan tersebut lebih luas dan ia dianggap tidak termasuk didalamnya dan perbuatan-perbuatan lain yang disebut antara lain bolos sekolah, melawan orang tua, lari dari rumah, bermalas-malasan serta beberapa perbuatan lain yang belum termasuk kategori tindak Pidana. 
DE LEGA LATA

Jurnal Ilmu Hukum

FAKULTAS HUKUM UMSU
Sistem Peradilan Edukatif...(Asliani Harahap)

Volume 3 Nomor 2, Juli-Desember 2018, 217-229

DOI: https://doi.org/10.30596/dll.v3i2.3152

Mengingat ciri dan sifat anak yang khas, maka dalam menjatuhkan pidana atau tindakan terhadap anak nakal haruslah dipertimbangkan pertumbuhan dan perkembangan mental anak sehingga perlu dibedakan perlakuan didalam hukum acara dan ancaman pidananya. Dalam hubungan ini pengaturan pengecualian dari ketentuan yang diatur dalam Undang-Undang Nomor 8 Tahun 1981 tentang Hukum Acara Pidana, yang lama pelaksanaan penahanannya ditentukan sesuai dengan kepentingan anak.

Penjatuhan hukuman penjara yang diberikan kepada anak sebagai pelaku kejahatan banyak sekali terjajdi contohnya kejahatan penyalahgunaan narkotika oleh anak. Hal ini menimbulkan suatu permasalahan, dimana faktor kejiwaan anak menjadi hal yang sangat utama, karena masalah psikologi atau kejiwaan ini mempengaruhi tumbuh dan berkembangnya si anak.

Sistem pemidanaan yang sampai sekarang terkadang masing memperlakukan anak-nak yang terlibat sebagai peaku tindak pidana itu seperti pelaku tindak pidana yang dilakukan oleh orang dewasa. Anak ditempatkan ddalam posisi sebagai seorang pelaku kejahatan yang patut untuk mendapatkan hukum yang sama dengan orang dewasa dan berlaku di Indonesia (Eva Rosasi Sitindaon, 2019).

Salah satu contoh sanksi pidana yang bersifat edukatif adalah pemberian sanksi pidana yang tidak hanya dikembalikan kepada orang tua/wali atau lingkungannya saja, namun sanksi Pidana tersebut sifatnya juga mendidik misalnya dimasukkan ke Pondok Pesantren bagi pelaku tindak pidana yang beragama muslim, atau diberikan kepada Gereja bagi yang beragama Nasrani, dan lembaga keagamaan lainnya yang sesuai dengan agama yang dipeluk atau dianutnya. Sistem pemidanaan dengan pemberian sanksi pidana yang bersifat edukatif / mendidik dan membina anak kearah kehidupan yang lebih baik, agar menjadi anggota masyarakat yang patuh kepada hukum. Sifat sanksi atau tindakan bagi anak harus berbeda dengan sifat snksi pidana bagi orang dewasa.

Pompe dan Marliana mengemukakan bahwa perbuatan Pidana ialah melanggar norma (kaidah: tata hukum) yang diadakan karena kesalahan pelanggar, dan harus diberikan pidana untuk mempertahankan tata hukum dan menyelamatkan kesejahteraan hukum. Andi Hamzah menyatakan bahwa Pidana dipandang sebagai suatu nestapa yang dikenakan kepada pembuat karena melakukan suatu delik (Marlina, 2012, h. 77). W.F.C Van Hattum didalam Ruslan Lenggong merumuskan bahwa Pidana itu suatu keseluruhan dari asas-asas dan peraturanperaturan yang diikuti oleh Negara atau suatu masyarakat hukum umum lainnya dimana mereka itu sebagai pemelihara dari ketertiban hukum umum yang telah melarang dilakukannya tindakan-tindakan yang bersifat melanggar hukum dan telah mengaitkan pelanggaran terhadap peraturan-peraturannya dengan suatu penderitaan yang bersifat khusus berupa hukuman (Ruslan Renggong, 2016, h. 13). Sedangkan menurut Van Hemel didalam Ruslan Renggong merumuskan bahwa hukum pidana adalah semua dasar-dasar dan aturanaturan yang dianut oleh suatu negara dalam menyelenggarakan ketertiban hukum (rechtsorde) yaitu denfggan melarang apa yang bertentangan dengan hukum dan mengenakan suatu nestapa kepada yang melanggar larangan-larangan tersebut (Ruslan Renggong, 2016, h. 14). 
Jurnal Ilmu Hukum

FAKULTAS HUKUM UMSU
Sistem Peradilan Edukatif...(Asliani Harahap)

Volume 3 Nomor 2, Juli-Desember 2018, 217-229

DOI: https://doi.org/10.30596/dll.v3i2.3152

Beberapa pendapat pakar hukum Indonesia mengenai Hukum Pidana, antara lain sebagai berikut: (Ruslan Renggong, 2016: 7-8).

1) Soedarto mengatakan bahwa hukum pidana merupaka sistem sanksi yang negatif, ia diterapkan jika sarana lain tidak memadai, maka hukum pidana dikatakan mempunyai fungsi subsidair, pidana termasuk juga tindakan (maatregelen), bagaimanapun juga merupakan suatu penderitaan, sesuatu yang dirasakan tidak enak oleh orang lain yang dikenai, oleh karena itu, hakekat dan tujuan pidana dan pemidanaan untuk memberikan alasan pembenaran (justification) pidana itu.

2) Roeslan Saleh mengatakan bahwa setiap perbuatan yang oleh masyrakat dirasakan sebagai perbuatan yang tidak boleh atau tidak dapat dilakukan sehingga perlu adanya penekanan pada perasaan hukum masyarakat. Oleh karena itu, sesuatu perbuatan pidana berarti perbuatan yang menghambat atau bertentangan dengan tercapainya tatanan dalam pergaulan yang dicita-citakan masyarakat. Sehingga isi pokok dari definisi hukum Pidana itu dapat disimpulkan sebagai berikut:

a) Hukum pidana sebagai hukum positif.

b) Substansi hukum pidana adalah hukum yang menentukan tentang perbuatan pidana dan menentukan tentang kesalahan bagi pelakunya.

3) Bambang Poernomo menyatakan bahwa hukum pidana adalah hukum sanksi, definisi ini diberikan berdasarkan ciri hukum pidana yang membedakan dengan lapangan hukum yang lain, yaitu bahwa hukum pidana sebenarnya tidak mengadakan norma sendiri melainkan sudah terletak pada lapangan hukum yang lain, dan sanksi pidana diadakan untuk menguatkan ditaatinya norma-norma diluar hukum Pidana.

Adapun tujuan dari hukum Pidana dikenal dua aliran yaitu:

1) Untuk menakuti-nakuti setiap orang jangan sampai melakukan perbuatan yang tidak baik (aliran Klasik).

2) Untuk mendidik orang yang telah pernah melakukan perbuatan tidak baik menjadi baik dan dapat diterima kembali dalam kehidupan lingkungannya (aliran modern).

Menurut aliran klasik tujuan hukum pidana untuk melindingi individu dari kekuasan penguasa atau negara, sedangkan menurut aliran modern mengajarkan tujuan hukum pidana untuk melindungi masyarakat terhadap kejahatan, dengan demikian hukum pidana harus memperhatikan kejahatan dan keadaan penjahat, demikian hukum pidana harus memperhatikan kejahatan dan keadaan penjahat, maka aliran ini mendapat pengaruh dari perkembangan kriminologi, dalam rancangan KUHP Juli 2006, tujuan pemidanaan ditentukan dalam Pasal 51, yaitu pemidanaan bertujuan mencegah dilakukannya tindak pidana dengan menegakkan norma hukum demi pengayoman masyarakat, memasyarakatkan terpidana dengan mengadakan pembinaan sehingga menjadi orang yang baik dan berguna, menyelesaikan konflik yang ditimbulkan oleh tindak Pidana memiluhkan keseimbangan dan mendatangkan rasa damai dalam masyarakat serta membebaskan rasa bersalah pada terpidana. Untuk mencapai tujuan pemidanaan dikenal sebagai tiga teori yaitu:

1) Teori pembalasan, diadakannya pidana adalah untuk pembalasan, teori ini dikenal pada akhir abad ke 18 dengan pengikut Immanuel Kant, Hegel, Hebert dan Stahl. 
Jurnal Ilmu Hukum FAKULTAS HUKUM UMSU
Sistem Peradilan Edukatif...(Asliani Harahap)

Volume 3 Nomor 2, Juli-Desember 2018, 217-229

DOI: https://doi.org/10.30596/dll.v3i2.3152

2) Teori tujuan atau relatif, jika teori absolut melihat kepada kesalahan yang sudah dilakukan, sebaiknya teori-teori relatif ataupun tujuan berusaha untuk mencegah kesalahan pada masa mendatang. Dengan perkataan lain pidana merupakan sarana untuk mencegah kejahatan, oleh karena itu juga sering disebut teori prevensi. Yang dapat kita tinjau dari dua segi, yaitu prevensi umum dan prevensi khusus.

3) Teori gabungan, gabungan dari dua teori diatas yaitu teori pembalasan dan teori tujuan atau relatif.

Tujuan hukum pidana ini sebenarnya mengandung makna pencegahan terhadap gejalagejala sosial yang kurang sehat disamping pengobatan bagi yang sudah terlanjur tidak berbuat baik (Ruslan Renggong, 2016, h. 14). Dalam kamus umum bahasa indonesia dapat dijumpai tiga pengertian asas sebagai berikut:

1) Dasar, alas, pedoman misalnya batu yang baik untuk alas rumah

2) Suatu kebenaran yang manjadi pokok atau tumpuan berpikir (berpendapat dan sebagainya; misalnya bertentangan dengan asas-asas hukum pidana; pada asasnya yang setuju dengan asal saudara)

3) Cita-cita yang menjadi dasar (perkumpulan negara dan sebagainya misalnya membicarakan asas dan tujuan

Berdasarkan ketiga pengertian tersebut dapat kita lihat pengertian yang esensial dari asas itu ialah: dasar, pokok tempat menemukan kebenaran dan sebagai tumpuan berpikir, tentang apa yang dimaksud dengan asas hukum banyak pengertian yang dikemukakan oleh para ahli hukum, yang antara lain; menurut C.W. Paton asas adalah suatu alam pikiran yang dirumuskan secara luas dan mendasari adanya suatu norma hukum. Untuk norma hukum itu sulit dicari asasnya, tetapi kalau ia menjadi asas, maka norma hukum itu sulit dicari asasnya, tetapi kalau ia menjadi asas, maka norma hukum itu sendirilah yang berfungsi sebagai asas. Maka asas hukum sebagai dasar pebentukan secara filosofi memiliki peranan yang sangat penting. P. Scolten menjelaskan bahwa asas hukum adalah kecendrungan-kecendrungan yang diisyaratkan oleh pandangan kesusilaan kita pada hukum yang merupakan sifat-sifat ummum dengan segala keterbatasannya sebagai pembawa hukum tetapi tidak boleh tidak harus ada. Sedangkan menurut bellefroid asas hukum ialah norma dasar yang dijabarkan dari hukum positif dan yang oleh ilmum hukum tidak dianggap berasal dari aturan-aturan yang lebih umum.

Aturan hukum pidanaa berlaku bagi setiap orang yang melakukan tindak pidana sesuai asas ruang lingkup berlakunya KUHP, asas ruang lingkup berlakunya aturan pidana itu ada empat ialah:

1) Asas Teritorialitas: asas terpokok dalam asas teritorialitas adalah tentang wilayah atau tertori dalam hubungannya dengan berlakunya undang-undang hukum pidana, dengan perkataan lain yang diutamakan ialah batas-batas teritori dimana undang-undang hukum pidana tersebut berlaku. Tetapi bilamana dihubungkan dengan pertindaknya, dalam hal ini yang menjadi permasalahan adalah batas-batas wilayah tempat petindak melakukan tindakannya, atau batas-batas wilayah dimana tindak pidana terjadi. 
Jurnal Ilmu Hukum

FAKULTAS HUKUM UMSU
Sistem Peradilan Edukatif...(Asliani Harahap)

Volume 3 Nomor 2, Juli-Desember 2018, 217-229

DOI: https://doi.org/10.30596/dll.v3i2.3152

2) Asas Nasionalitas Aktif: asas ini adalah orang, person dalam hal ini berlakunya huum pidana dikaitkan dengan orangnya, tanpa mempersoalkan dimana orang itu berada, yaitu didalam maupun diluar Negara Indonesia.

3) Asas Nasionalitas Pasif: asas ini adalah setiap negara yang berdaulat wajib melindungi kepentingan hukumnya atau kepentingan nasional.

4) Asas Univeersal: semula tiada dirasakan akan adanya keperluannya untuk mengadili seorang penjahat yang bukan warga negara dan bukan penduduk dari suatu negara, kendati ia berada dinegara itu, jika kejahatan tersebut tidak merugikan kepentingan perseorangan atau hukum dari negara yang bersangkutan, akan tetapi sesuai dengan perkembangan teknologi yang membuat jarak-jarak semakin dekat, maka beberapa kepentingan tertentu sangat dirasakan oleh pemerintah negara-negara sebagai kepentingan bersama yang harus ditanggunglangi secara bersama pula.

Menurut Hugo Sinzheimer, pengertian hukum mencakup hukum normatif, hukum ideal dan kenyataan hukum. Dengan demikian ruang lingkup ilmu hukum mengikuti pandangan Hugo Sinzheimer, adalah juga mencakup ilmu-ilmu yang mempunyai pokok bahasan dari ketiga bentuk perwujudan hukum tersebut.

Berdasarkan beberapa pengertian dan ruang lingkup pemidanaan tersebut dapat diketahui bahwa pidana selalu mengandung unsur-unsur: kesengajaan (Marlina, 2012: 78).

1) Unsur Objektif

a) Perbuatan manusia yang termasuk unsur-unsur pokok Objektif sebagai act ialah perbuatan aktif yang disebut juga perbuatan positif dan ommision ialah tidak aktif berbuat dan disebut juga perbuatan negatif

b) Akibat perbuatan manusia. Akibat yang dimaksud ialah membahayakan atau menghilangkan kepentingan yang diperhatikan oleh hukum

c) Keadaan dibedakan pada perbuatan dan keadaan setelah perbuatan

d) Sifat dapat dihukum dan sifat melawan hukum

2) Unsur Pokok Subjektif:

a) Kesengajaan, terdiri dari tiga bentuk, yakni sengaja sebagai maksud sengaja sebagai kepastian dan sengaja sebagai kepentingan

b) Kealpaan adalah bentuk kesalahan yang lebih ringan dari pada.

Sedangkan menurut Moelyatno unsur atau elemen perbuatan pidana terdiri dari: (Teguh Prasetyo, 2015, h. 52).

1) Kelakuan dan akibat (perbuatan)

2) Hal ikhwal atau keadaan yang menyertai perbuatan

3) Keadaan tambahan yang memberatkan pidana

4) Unsur melawan hukum yang objektif

5) Unsur melawan hukum yang subjektif

Kitab Undang-undang Hukum Pidana di Indonesia jelas terkandung makna bahwa suatu perbuatan pidana (kejahatan) harus mengandung unsur-unsur: (Wagiati Soetedjo, 2013).

1) Adanya perbuatan manusia

2) Perbautan tersebut harus sesuai dengan ketentuan hukum 
DE LEGA LATA

Jurnal Ilmu Hukum

FAKULTAS HUKUM UMSU
Sistem Peradilan Edukatif...(Asliani Harahap)

Volume 3 Nomor 2, Juli-Desember 2018, 217-229

DOI: https://doi.org/10.30596/dll.v3i2.3152

3) Adanya kesalahan

4) Orang yang berbuat harus dapat dipertanggungjawabkan

Sudikno Mertokusumo mengemukakan tujuan pokok hukum adalah menciptakan tatanan masyarakat yang tertib, masyarakat ketertiban dan keseimbangan. Dengan tercapainya ketertiban didalam masyarakat diharapkan kepentingan manusia akan terlindungi. Dalam tercapainya tujuannya itu hukum bertugas membagi hak dan kewajiban antar perorangan didalam masyarakat. Membagi wewenang dan mengatur cara memecahkan masalah hukum serta memelihara kepastian hukum. Tujuan dibuatnya ketentuan Pidana dan tindakan dalam Undang-Undang Nomor 11 tahun 2012 tentang Sistem Peradilan Pidana Anak yang berada dengan ketentuan pidana dalam KUHP, dimaksudkan untuk lebih melindungi dan mengayomi anak. Selain itu menurut penjelasan umum Undang-undang Nomor 11 tahun 2012 tentang Sistem Peradilan Pidana Anak pembedaan tersebut dimaksudkan untuk memberi kesempatan kepada anak agar melalui pembinaan akan memperoleh jati dirinya untuk menjadi manusia yang mandiri, bertanggung jawab dan berguna bagi diri, keluarga, masyarakat, bangsa dan negara.

KUHP menganut sistem dua jalur dalam pemidanaan yaitu disamping pembuat tindak pidana dapat dijatuhi pidana, dapat juga dikenakan berbagai tindakan. Penetapan sanksi berupa tindakan ini harus sesuai dengan tujuan pemidanaan dan pedoman pemidanaan. Sistem pemidanaan dua jalur secara teoritis telah dianut dalam KUHP, namun sanksi tindakan hanya diperuntukan bagi orang yang tidak mampu bertanggung jawab dan anak dibawah umur. Perkebangannya, perundang-undangan diluar KUHP telah menerima konsep perluasan pengenaan jenis sanksi tindakan yang juga dapat diancamkan terhadap orang yang tidak mampu bertanggung jawab dan korporasi sebagai pelaku tindak pidana.

Jenis tindakan dalam pola pemidanaan dalam beberapa regulasi di Indonesia ini hanya dianggap sebagai sanksi yang bersifat komplementer atau pelengkap dan tidak ada bedanya dengan jenis sanksi Pidana tambahan yang bersifat fakultif. Meskipun juga telah ada sanksi tindakan yang bersifat mandiri atau sebagai sanksi alternatif, misalnya dalam Undang-Undang Nomor 3 Tahun 1997 tentang Pengadilan Anak, namun tidak ada penjelasan yang memadai mengenai argumentasi atau landasan pengenaan sanksi tindakan yang bersifat mandiri tersebut. Di dalam Pasal 2 dan 3 Undang-Undang Nomor 11 Tahun 2012 menyatakan bahwa;

Sistem peradilan pidana anak dilaksanakan berdasarkan asas perlindungan, keadilan, nondiskriminasi, kepentingan terbaik bagi anak, penghargaan terhadap pendapat anak, kelangsungan hidup dan tumbuh kembang anak, pembinaan dan pembimbingan anak, proporsional, perampasan kemerdekaan dan pemidanaan sebagai upaya terakhir dan penghindaran pembalasan (Muhammad Taufik Makarao, 2011, h. 67).

Perumusan dan penegasan tentang sistem penggunaan double track system dengan mengatur secara khusus tentang sanksi tindakan menunjukkan bahwa pandangan baru yang diadopsi menuju ke sistem pemidanaan yang sesuai dengan tujuan pemidanaan. Tindakangan sebagai bentuk sanksi hukum terhadap anak pelaku tindak pidana merupakan ketentuan baru yang selama ini didalam KUHP tidak ditentukan khusus terhadap anak. Pidana terhadap anak 
dalam Undang-undang Nomor 11 Tahun 2012 tentang Sistem Peradilan Pidana Anak diatur pada Pasal 71 ayat 1 yaitu pidana pokok bagi anak terdiri atas:

1) Pidana peringatan

2) Pidana dengan syarat:

a) Pembinaan diluar lembaga

b) Pelayanan masyarakat

c) Pengawasan

d) Pelatihan kerja

e) Pembinaan dalam lembaga

f) Penjara

Ketentuan pasal 71 ayat 2 Undang-Undang Nomor 11 Tahun 2012 Tentang Sistem Peradilan Pidana Anak menentukan selain Pidana Pokok sebagaimana dalam ayat 1 terhadap anak yang berkonflik dengan hukum dapat juga dijatuhi hukuman pidana tambahan yang terdiri dari:

1) Perampasan keuntungan yang diperoleh dari tindak pidana

2) Pemenuhan kewajiban adat

Hukum materil yang menentukan ancaman pidana kumulatif berupa penjara dan denda, pidana denda diganti dengan pelatihan kerja, pidana yang dijatuhkan kepada anak dilarang melanggar harkat dan martabat anak. Ketentuan mengenai tindakan anak, Pasal 82 ayat 1 Undang-undangan Nomor 11 Tahun 2012 tentang Sistem Peradilan Pidana Anak berbunyi;

Tindakan yang dapat dijatuhkan kepada anak ialah:

1) Pengembalian kepada orang tua/wali

2) Penyerahan kepada seseorang

3) Perawatan dirumah sakit jiwa

4) Perawatan di LPKS (Lembaga Penyelenggaraan Kesejahteraan Sosial)

5) Kewajiban mengikuti pendidikan formal dan/atau pelatihan yang diadakan oleh pemerintah atau badan swasta

6) Pencabutan surat izin mengemudi

7) Perbaikan akibat tindak Pidana

Tindakan penyerahan anak kepada seseorang dilakukan untuk kepentingan anak yang bersangkutan. Tindakan perawatan terhadap anak dimaksudkan untuk membantu orang tua / wali dalam mendidik dan memberikan pembimbingan kepada anak yang bersangkutan. Ketentuan Undang-Undang Nomor 11 Tahun 2012 tentang Sistem Peradilan Pidana Anak terhadap anak yang belum berumur 12 Tahun dan melakukan tindak pidana sebagaimana dimaksud dalam pasal 1 angka 3 huruf a. Yang diancam denga pidana penjara sementara waktu, tidak diancam dengan hukuman mati atau seumur hidup tidak dijatuhkan sanksi akan tetapi dikenakan tindakan. Untuk dapat diajukan kedepan sidang pengadilan anak, maka anak nakal minumum telah berumur 8 tahun dan maksimum 18 tahun. Sementara anak yang belum berumur 8 tahun walaupun melakukan tindak pidana belum dapat diajukan kesidang Pengadilan Anak. Ini didsarkan pada pertimbangan sosiologis, psikologis dan paedagogis, 
bahwa anak yang belum berumur 8 tahun itu belum dapat mempertanggungjawabkan perbuatannya. Akan tetapi dalam hal anak itu melakukan tindak pidana dalam batas umur 8 tahun, akan tetapi belum mencapai 18 tahun maka ia diajukan kepengadilan anak.

Berdasarkan ketentuan sanksi dan tindakan dalam Undang-Undang Nomor 11 tahun 12 Tentang Sistem Peradilan Pidana Anak tersebut, eksistensinya sangat menentukan dalam perlindungan hukum terhadap anak yang melakukan tindak pidana, sistem pertanggungjawab pidana anak pada dasarnya masih sama dengan sistem pertanggung jawab orang dewasa, yaitu berorientasi pada si pelau secara pribadi/individual.

Sistem pemidanaan yang berlaku saat ini di Indonesia hanya bertumpu sifat pemidanaannya saja tanpa memperhatikan bagaimana dapat merubah sianak tersebut menjadi lebih baik. Diberikannya sistem pemidanaan yang bersifat edukatif, yaitu suatu sistem pemidanaan yang tidak hanya menekankan dari segi pemidanaannya saja namun lebih kepada bagaimana caranya agar seseorang anak itu bisa dirubah perilakunya menjadi lebih baik dan tidak akan mengulangi tindakannya tersebut tanpa harus diberikan sanksi badan atau penjara.

\section{KESIMPULAN DAN SARAN}

\section{Kesimpulan}

Sistem pemidanaan yang bersifat edukatif harus menjadi prioritas hakim dalam menjatuhkan putusan terhadap anak pelaku tindak pidana, sebab pemidanaan yang akan dijalankan di penjara adalah pilihan terakhir. Sistim pemidanaan yang bersifat edukatif ini harus berbeda dengan sistim pemidanaan orang dewasa. Sistim pemidanaan edukatif adalah upaya untuk memperhatikan masa depan anak agar lebih baik dengan menempatkan anak pada sekolah khusus agar mendapat bimbingan baik secara moral maupun intelektual untuk mendapatkan pengetahuan dan keterampilan sebagai bentuk perlindungan terhadap anak yang bermasalah dengan hukum.

\section{Saran}

Bahwa sudah saatnya regulasi terkait pemidanaan untuk anak dibuat secara khusus, hal ini diperuntukkan memberikan kepastian hukum bagi hakim atas anak yang telah dinyatakan bersalah akibat melanggar aturan hukum, pertimbangan hakim terkait pemidanaan edukatif ini sangat penting, namun tidak jauh pentingnya juga atas kejelasan regulasinya agar setiap hakim memiliki pijakan hukum yang pasti dalam pertimbangan hukum yang dibuatnya. 
Jurnal Ilmu Hukum FAKULTAS HUKUM UMSU
Sistem Peradilan Edukatif...(Asliani Harahap) Volume 3 Nomor 2, Juli-Desember 2018, 217-229 DOI: https://doi.org/10.30596/dll.v3i2.3152

\section{DAFTAR PUSTAKA}

Ali, Zainudin. (2011). Metode Penelitian Hukum. Jakarta: Sinar Grafika.

Haekal, Muhammad Husein. (1984). Sejarah Hidup Muhammad. Jakarta: Tintamas.

Hamdani, Ikhwan. (2003). Sistem Pasar, Pengawasan Ekonomi (Hisbah) dalam Persepektif Ekonomi Islam. Jakarta: Nur Insani.

Junaidi, Wawan. (2006). Rekonsepsi Al-Istihalah dan Implikasinya Terhadap Hala-Haram Bahan Pangan Dengan Pendekatan Ilmu Kimia. Jakarta: Badan Litbang dan Diklat Departemen Agama RI.

Jusmaliani. (2008). Bisnis Berbasis Syari'ah. Jakarta: Bumi Aksara.

Konoras, Abdurrahman. (2017). Jaminan Produk Halal Di Indonesia Perspektif Hukum Perlindungan Konsumen. Jakarta: Rajagrafindo Persada.

Majelis Ulama Indonesia. (2012). Fatwa Majelis Ulama Indonesia (MUI) dalam Persepektif Hukum dan Perundang-Undangan. Jakarta: Badan Litbang dan Diklat Kementrian Agama Republik Indonesia.

Muhammad, Abdulkadir. (2004). Hukum dan Penelitian Hukum. PT. Citra Aditya.

Rahman, Afzalul. (2000). Muhammad Sebagai Seorang Pedagang. Jakarta: Swarna Bhumi.

Shabiri, Abul Futuh. (2017). Sukses Bisnis Berkat Wasiat Nabi. Jakarta: Pustaka Al-Kausar.

Sidik, H. Salim., \& Nurbani, Erlies Septiana. (2017). Penerapam Teori Hukum Pada Penelitian Tesis dan Disertasi. Jakarta: Rajagrafindo Persada.

Undang-Undang Nomor 7 Tahun 1996.

Undang-Undang Nomor 18 Tahun 2012 tentang Pangan.

Undang-Undang Nomor 33 Tahun 2014 tentang Jaminan Produk Halal.

Undang-Undang Nomor 8 Tahun 1999 tentang Perlindungan Konsumen.

Uways, Abdul Halim. (1998). Fikih Statis-Dinamis (terjemahan Zarkasyi Chumaidy, dari AlFiqh al-Islamiy Bayn at-Taqawwur wa as-Sabat). Bandung: Pustaka Hidayah.

Zulham. (2013). Hukum Perlindungan Konsumen. Jakarta: Pranadamedia Group. 